\title{
Review Articles: Editorial Note
}

This issue of the American Bar Foundation Research Journal carries on the following pages a review article written by a Foundation research staff member who bas special knowledge in the area of the reviewed book's content. The editors of the reviewed book will of course be given space for a response, and one is expected to appear in the next issue.

From time to time the American Bar Foundation Research Journal may publisb such review articles (but not ordinary book reviews). When it does, it will offer its pages to authors for reasoned replies at appropriate length. When deadlines permit, the review article and the response will appear simultaneously. Unfortunately that was not possible in this case. The Research Journal will publish only those responses, bowever, that meet its standards both in substance and in writing style. Whether these standards bave been satisfied rests in the sole judgment of the editor, the Executive Director of the American Bar Foundation.

Spencer L. Kimball

Editor 